


\title{
Krasno polje on Velebit Mountain: morphographic and morphogenetic characteristics
}

\author{
Krasno polje na Velebitu: morfografske \\ i morfogenetske karakteristike
}

Krasno polje is one of the less typical karst poljes within the Dinaric Mountains. It is situated within Velebit Mountain. Our research utilized morphographic, morphostructural and morphometric analysis of the polje to present its morphogenetic characteristics. It is completely filled with gravel and lacking any surface flows. Slopes above the polje were severely altered by glacial action during the colder periods of the Pleistocene. As a result, proglacial fans filled the karst depression, creating a piedmont type polje. Glacial evidence suggests that there were at least two separate phases of intense proglacial deposition within the polje.

Key words: Dinaric Mountains, the Velebit Mountain, polje, glaciation, Croatia
Krasno polje tipično je krško polje u Dinarskom gorju. Smješteno je na planini Velebit. U istraživanju smo primijenili morfografske, morfostrukturne i morfometrijske analize polja kako bismo prikazali njegove morfogenetske karakteristike. Polje je u potpunosti ispunjeno šljunkom, a površinskih tokova nema. Padine iznad polja uvelike su izmijenjene glacijalnim procesima tijekom hladnijeg razdoblja pleistocena, zbog čega je proglacijalna lepeza ispunila kršku depresiju i stvorila pijedmontski tip polja. Glacijalni dokazi sugeriraju postojanje dviju odvojenih faza intenzivne proglacijalne akumulacije polja.

Ključne riječi: Dinarsko gorje, Velebit, polje, glacijacija, Hrvatska 
HRVATSKI

GEOGRAFSKI

GLASNIK

77/2, 85-99 (2015.)

\section{Introduction}

The Dinaric Mountains, with a length of $645 \mathrm{~km}$ and a width of $150 \mathrm{~km}$, are one of the largest contiguous mountain belts in Europe. They are positioned between the Pannonian Basin in the northeast and the Adriatic Sea in the southwest. They are characterized by different natural stripes whose morphology is influenced by lithology differences. Fluvial relief prevails inland on non-carbonate rocks, though the centraland outer stripes are formed mostly of limestone and dolostones, karst landscape is dominant. The karst areas of the Dinaric Mountains are characterized by extensive mountains, large levelled corrosion plains and intramontane basins that host karst poljes along with smaller karst features such as uvalas, sinkholes, canyons, dry valleys and collapse sinkholes, which are dissecting the whole relief (Mihevc, 2010).

\section{Uvod}

Dinarsko gorje, duljine $645 \mathrm{~km}$ i širine od oko $150 \mathrm{~km}$, jedan je od najvećih planinskih masiva istočnog dijela euroazijskog orogena. Smješteno je između panonskog bazena na sjeveroistoku i Jadranskog mora na jugozapadu. Karakteriziraju ga različiti prirodni pojasevi čija je morfologija uvjetovana litološkim razlikama. Tako u unutrašnjosti na nekarbonatnim stijenama prevladava fluvijalni reljef, a u središnjem i vanjskim pojasevima, sastavljenima većinom od vapnenca i dolomita, krški reljef. Krške predjele Dinarskoga gorja karakteriziraju velike planine, zaravni i depresije s krškim poljima te isprekidanost reljefa manjim krškim oblicima poput uvala, ponikva, suhih dolina i urušnih ponikva (Mihevc, 2010).

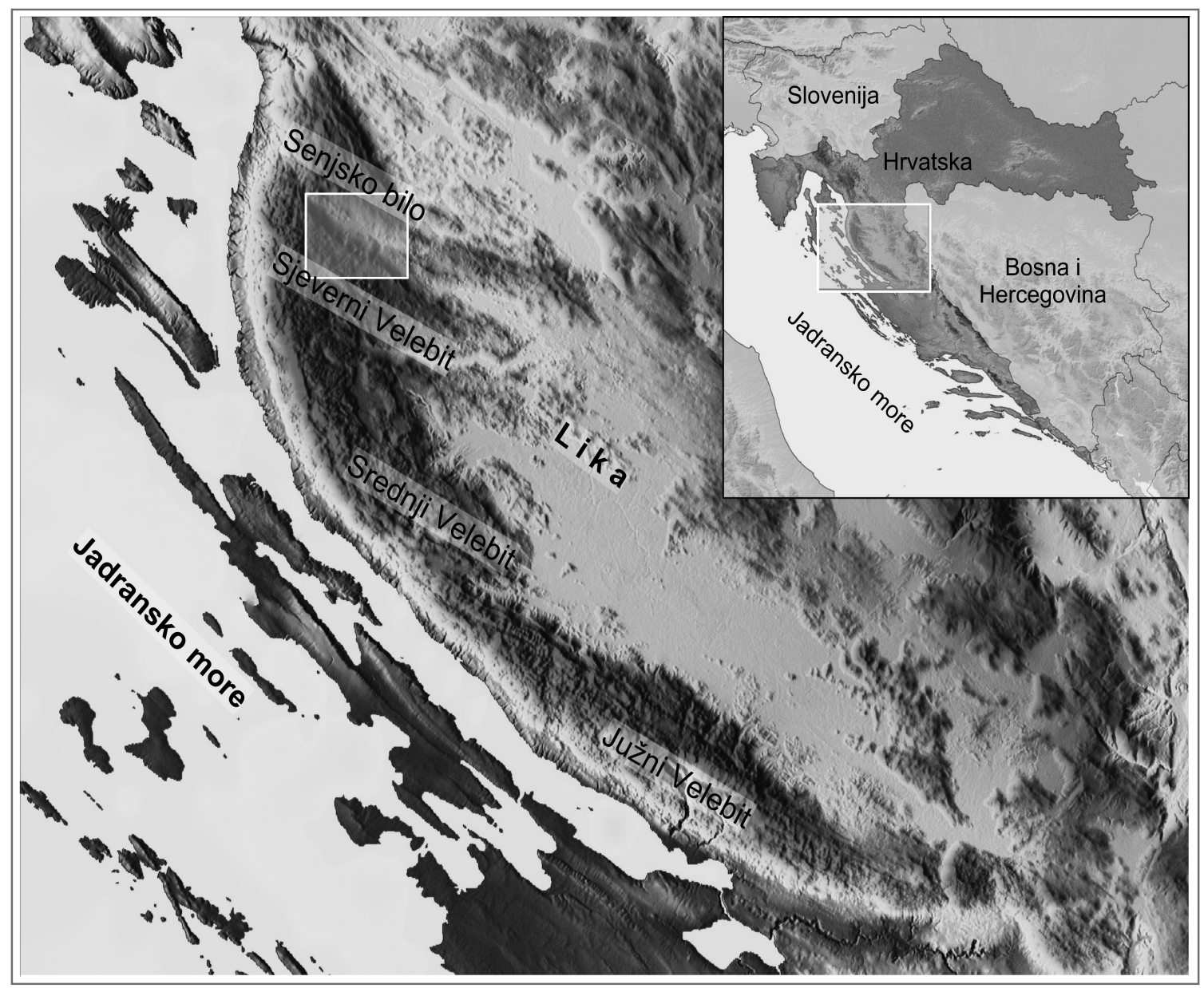

Fig. 1 The study area

SI. 1. Područje istraživanja 
Around 130 poljes were defined in the Dinaric karst (Gams, 1978) that are elongated along the strike of the Dinaric Mountains that runs in a northwest-southeast direction. This is a consequence of development along regional fault lines, graben structures or overthrusts. Karst poljes are the largest closed depressions in karst, which can be distinguished from other depressions for their large flat floors.

Velebit is situated within the north-western part of the Dinaric Mountains above the Adriatic coast. With its $145 \mathrm{~km}$ length and about $15 \mathrm{~km}$ width, it is the biggest massif within the Dinaric Mountains. It covers an area of about $2270 \mathrm{~km}^{2}$ and it is limited by the Lika region towards the east and Zrmanja and Krupa canyons towards the south and southeast. Lower relief within the Velebit Mountain hosts Oštarijsko polje (Perica et al., 2002) and Krasno polje. The aim of this article is to present morphographic and morphometric analysis of Krasno polje, to define its morphogenesis, its hydrologic function and to present its morphocronology.

\section{Regional characteristics of Krasno polje}

Krasno polje is positioned within the northern Velebit Mountain east of the Oltari pass. The depression of Krasno polje is situated between the highest part of the northern Velebit Mountain and its lower continuation, Senjsko Bilo, to the north. The depression has an elongated shape oriented in a northwest - southeast direction. The elevation of the polje at its highest part is about $850 \mathrm{~m}$, from where it gently lowers to an elevation of $660 \mathrm{~m}$ on the southeastern side. The polje consists of three separated enlargements. The northwestern enlargement named Jerkuše is $800 \mathrm{~m}$ wide and about $1700 \mathrm{~m}$ long. The enlargement in the central part is named Veliko polje and it is $600 \mathrm{~m}$ wide and $1700 \mathrm{~m}$ long. The lowest enlargement, which is positioned on the southeast, is named Malo polje and it is 300 $\mathrm{m}$ wide and $600 \mathrm{~m}$ long. Slopes above the polje on the northern and eastern sides are well-karstified, covered with karren and sinkholes. The southern slopes are also karstified but they are much steeper and covered with karren. Sinkholes are practically absent due to steep slopes that are active (Stepišnik and Kosec, 2012).
U dinarskom kršu definirano je oko 130 polja (Gams, 1978), koja su većinom oblikovana u smjeru pružanja Dinarskoga gorja, sjeverozapad-jugoistok. Uzrok tomu njihovo je razvijanje duž regionalnih rasjeda, tektonskih jaraka ili navlaka. Krška polja najveće su zatvorene depresije u kršu, koje se od ostalih zatvorenih depresija razlikuju svojom veličinom i ravnim dnom.

Velebit je smješten na sjeverozapadnom dijelu Dinarskoga gorja, a uzdiže se iznad jadranske obale. S duljinom od $145 \mathrm{~km}$ i prosječnom širinom od oko $15 \mathrm{~km}$ najveća je planina Dinarskoga gorja. Zauzima površinu od oko $2270 \mathrm{~km}^{2}$, a omeđuju ga Lika na istoku te kanjoni Zrmanje i Krupe na jugu i jugoistoku. $\mathrm{Na}$ nižim predjelima Velebita nalaze se Oštarijsko polje (Perica i dr., 2002) i Krasno polje. Cilj rada jest predstavljanje rezultata morfografske i morfometrijske analize Krasnog polja, definiranje morfogeneze polja i načina njegove hidrološke funkcije te predstavljanje njegove morfokronologije.

\section{Regionalna svojstva Krasnog polja}

Krasno polje smješteno je na sjevernom Velebitu istočno od prijevoja Oltari. Depresija Krasnog polja prostire se na području najviših dijelova sjevernog Velebita i njegova nižeg nastavka Senjskog bila na sjeveru. Depresija je izdužena oblika i pruža se u smjeru sjeverozapad-jugoistok. Visina Krasnog polja na najvišem je dijelu oko $850 \mathrm{~m}$, odakle se blago spušta do visine od oko $660 \mathrm{~m}$ na jugoistočnoj strani. Polje se sastoji od triju međusobno povezanih proširenja. $\mathrm{Na}$ sjeverozapadnom proširenju, na toponimu Jerkuše, široko je 800, a dugačko oko 1700 metara. $\mathrm{Na}$ središnjem proširenju, Velikom polju, širina je 600, a duljina 1700 metara. Najniže proširenje, koje se nalazi na jugoistoku, jest Malo polje, široko 300, a dugačko 600 metara. Iznad polja, na sjevernim $\mathrm{i}$ istočnim padinama, ističe se dobro razvijeni krš prekriven škrapama i ponikvama. Južne padine također su krške, mnogo strmije i prekrivene škrapama. Ponikva međutim gotovo da i nema zbog visokog nagiba padine koja je aktivna (Stepišnik i Kosec, 2011).
U. Stepišnik

Krasno polje on Velebit Mountain: morphographic and morphogenetic characteristics

Krasno polje na Velebitu: morfografske i morfogenetske karakteristike 
Northern Velebit was intensively modified by glacial processes during the Pleistocene (Bognar et al., 1991a; Bognar et al., 1991b; Faivre, 1991). Current literature quotes that glaciers which occupied an area of about 115 $\mathrm{km}^{2}$ were positioned at elevations higher than $1300-$ $1400 \mathrm{~m}$. On the southern slopes above Krasno polje, three glacial cirques were identified: Žestikovac, Splitvina and Ripljevica (Bognar et al., 1991a; Bognar et al., 1991b; Faivre, 1991). These cirques were supposedly functioning as heads for small scale cirque glaciers, which were between 750 to $1000 \mathrm{~m}$ long. They were connected to the glacial plateau at Jezera only during the peaks of glaciation. The only two reported sites where glacial material was identified were below Ripljevica cirque in the area of Trapolovica and within Žestikovac valley (Bognar et al., 1991a; Bognar et al., 1991b; Faivre, 1991). Proglacial glaciofluvial accumulations, which consist of pebbly material, infilled parts of the Krasno polje floor (Bognar et al., 1991a; Bognar et al., 1991b; Faivre, 1991).

In the lithological sense, Krasno polje area is filled with Quaternary fluvioglacial material. Its northern escarpments are built of Middle Jurassic grey and dark grey limestone with layers of dolomitised limestone. The southern slopes are comprised of Lower Jurassic well-bedded grey limestone and dolostone. Krasno polje is positioned in an area of lowered relief which is oriented along the Krasno polje fault. This fault is one of the most prominently expressed geological structures running in a perpendicular direction to the main ridge of Velebit Mountain (Sokač et al., 1970; Velić, Velić, 2009).

Steep slopes above the Adriatic Sea makes Mount Velebit an effective barrier for orographic precipitation. The average annual rainfall in the area of Krasno polje is $2538 \mathrm{~mm}$ (Perica, Orešić, 1999) and the average annual temperature is $8.3^{\circ} \mathrm{C}$ (Medvedović et al., 2009). With no recorded flooding of any section of the floor we can conclude that, in a hydrologic sense, the polje is positioned completely in a vadose zone. The thickness of the vadose zone in the area of the polje is not known.

There is a riverbed running along the whole length of the polje. According to the local legends, it was filled by $r$ Krasica River, which was supposedly drained during the Dubrovnik earthquake in 1667 (Glavičić, 1981). The name of the village of Krasno was derived from the name of this river (Glavičić, 1981). Today, there are no periodical or permanent surface streams on any part of the polje.
Sjeverni predjeli Velebita uvelike su modificirani glacijalnim djelovanjem tijekom pleistocena (Bognar i dr., 1991a, 1991b; Faivre, 1991).U literaturi se ističe kako su ledenjaci zauzimali područje od oko $115 \mathrm{~km}^{2}$ te su se nalazili iznad $1300-1400 \mathrm{~m} \mathrm{n}$. v. $\mathrm{Na}$ južnoj padini iznad Krasnog polja identificirana su i tri ledenjačka cirka: Žestikovac, Splitvina i Ripljevica (Bognar i dr., 1991a, 1991b; Faivre, 1991). Iz tih cirkova istjecali su manji ledenjaci duljine od 750 do $1000 \mathrm{~m}$. S glacijalnim platoom na Jezerima bili su povezani samo tijekom maksimuma oledbe. U stručnoj literaturi zabilježene su dvije lokacije na kojima se pojavljuje glacijalni materijal: podno cirka Ripljevica na predjelu Trapolovica i u dolini Žestikovac (Bognar i dr., 1991a, 1991b; Faivre, 1991). Proglacijalne glaciofluvijalne plavine od šljunka zapunjavaju dijelove dna Krasnog polja (Bognar i dr., 1991a, 1991b; Faivre, 1991).

Litološki, prostor Krasnog polja ispunjen je kvartarnim fluvioglacijalnim materijalom. Njegove sjeverne padine grade srednjojurski sivi i tamnosivi vapnenci sa slojevima dolomitiziranog vapnenca. Južne padine grade donjojurski slojeviti sivi vapnenci i dolomiti. Polje je smješteno u udubljenju koje je nastalo uz rasjed Krasnog polja. Upravo je taj rasjed jedan od najznačajnijih na Velebitu i pruža se pravokutno u odnosu na smjer glavnoga grebena Velebita (Sokač i dr., 1970; Velić i Velić, 2009).

Strme padine Velebita koje se uzdižu iznad Jadranskog mora čine tu planinu učinkovitom barijerom za orografske padaline. Prosječna godišnja količina padalina koja je izmjerena na području Krasna iznosi 2538 mm (Perica i Orešić, 1999), a prosječna godišnja temperatura $8,3{ }^{\circ} \mathrm{C}$ (Medvedović i dr., 2009). Budući da nema izvještaja o poplavama ni na jednom dijelu polja, možemo zaključiti da je u hidrološkom smislu polje u potpunosti pozicionirano u vadoznoj zoni. Dubina vadozne zone na području polja nije poznata.

$\mathrm{Na}$ polju postoji i riječno korito koje se pruža cijelom njegovom duljinom. Prema lokalnim legendama, poljem je tekla rijeka Krasica, koja je, navodno, nestala tijekom potresa u Dubrovniku 1667. Po toj je rijeci Krasno, navodno, dobilo ime (Glavičić, 1981).Danas ni na jednom dijelu polja ne postoje periodični ni stalni površinski tokovi. 


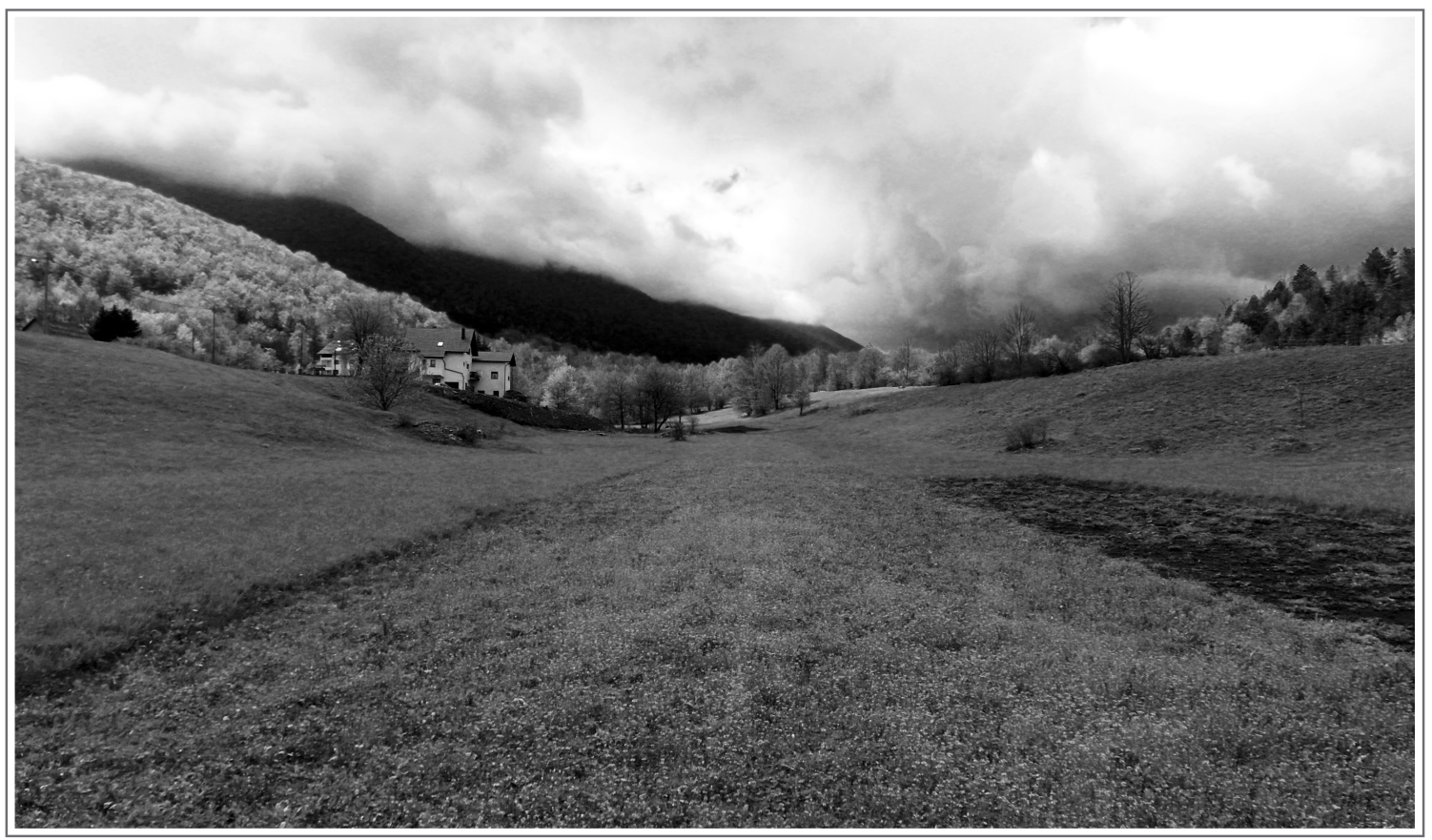

Fig. 2 Dry riverbed in the Veliko polje area

SI. 2. Suho riječno korito na području Velikog polja

\section{Definitions of Karst poljes}

The term karst polje was first used by Mojsisowicz (1880) in the context of describing karst in Bosnia. Cvijić (1900) provided the first morphographic and morphometric descriptions in which he specified that a karst polje must be a great depression with a floor levelled by Tertiary sedimentation. In addition he stressed that their longer axis is parallel to local geologic structures and their hydrologic functions should be connected to the subsurface outflow. He suggested that those geomorphologic features are the final phase of evolution of the poljes from dolines trough uvalas (Cvijić, 1900). Grund (1903) defined karst poljes as closed depressions with a rim higher than their floor, thus excluding some other types of open depressions from being defined as poljes. Cvijić (1900) and Grund (1903) with their explanations of the term polje have set the basis for all further definitions (e.g. Šerko, 1947; Lehmann, 1959; Roglić, 1964; Monroe, 1970; Gèze, 1973; Sweeting, 1973; Gavrilović, 1974).

The first systematic typization of poljes was implemented by Gams (1974). He established five types of karst poljes according to their hydrological function.(1) $A$ Border type polje is formed along the contact zone of per-
U. Stepišnik

Krasno polje on Velebit Mountain: morphographic and morphogenetic characteristics

Krasno polje na Velebitu: morfografske i morfogenetske karakteristike

\section{Definicije krških polja}

Mojsisovicz (1880) prvi je upotrijebio stručni termin krško polje opisujući krš u Bosni. Cvijić (1900) napravio je prve morfografske i morfometrijske opise specificirajući da krška polja moraju biti velike depresije sa zaravnjenim dnom s tercijarnim sedimentima. Osim toga istaknuo je da duža os strukture definirane kao polje treba biti paralelna s lokalnom geološkom strukturom, a njezina hidrološka funkcija povezana s podzemnim otjecanjem. Smatrao je i da su te geomorfološke jedinice posljednja faza u evolutivnom slijedu od ponikva preko uvala do oblika polja (Cvijić, 1900). Grund (1903) definirao je krškim poljima samo zatvorene kotline s obodom višim od dna, čime su sve otvorene depresije isključene iz definicije polja. Cvijić (1900) i Grund (1903) svojim definicijama krškog polja postavili su osnovu za sve sljedeće definicije termina polje (npr. Šerko, 1947; Lehmann, 1959; Roglić, 1964; Monroe, 1970; Gèze, 1973; Sweeting, 1973; Gavrilović, 1974).

Prvu sistematsku tipologiju polja uveo je Gams (1978). Krška polja podijelio je u pet tipova s obzirom na njihovu hidrološku funkciju. Rubno polje formira- 
HRVATSKI

GEOGRAFSKI

GLASNIK

77/2, 85-99 (2015.) meable and impermeable rocks from where waters drain into karst. (2) An overflow type polje has either a stripe or the whole floor built of impermeable or semipermeable sediments, which act as a barrier for underground water emerging on the surface at one side and submerging at another side of the polje floor.(3) A peripheral type polje is of impermeable sediments in the central part of the polje from where waters are radiating towards the ponors in bordering limestone. (4) A piedmont type polje is positioned at the foot slope of a mountain and was filled by extensive quantities of alluvium during glacial or periglacial conditions of the Pleistocene. (5) A type of polje in the piezometric level is regularly inundated solely by karst groundwater oscillations.

Recent scientific literature regarding karst poljes (e.g. White, 1988; Ford and Williams, 2004) uses hydrology based typizations introduced by Gams (1978). However, general definitions for the morphometry of karst poljes are still questioned. Some authors claim that size does not matter (Ford, Williams, 2004), while others suggest that the minimal width of a polje should be $400 \mathrm{~m}$ (Gams, 1974) and still others 1- $5 \mathrm{~km}$ (Jennings, 1985; White, 1988). no je na kontaktnom području propusnih i nepropusnih stijena gdje voda iz nepropusnih stijena otječe u krš. Preljerno polje ima pojas ili čitavo dno izgrađeno od nepropusnih ili polupropusnih sedimenata koji funkcioniraju kao barijera podzemnim vodama koje izviru na jednoj, a poniru na drugoj strani polja. $P_{e-}$ riferno polje čine nepropusni sedimenti u središnjem dijelu polja, odakle vode otječu prema ponorima na njegovu rubu. Piedmontsko polje nalazi se podno planinskih padina koje su tijekom pleistocenskih glacijalnih ili periglacijalnih procesa ispunjene velikom količinom aluvija. Polje na piezometričnoj razini redovito je poplavljeno isključivo zbog oscilacije krških podzemnih voda.

Suvremena znanstvena literatura o krškim poljima (npr. White, 1988; Ford i Williams, 2007) upotrebljava tipove koje je na osnovi hidroloških funkcija razvio Gams (1978). No osnovne definicije o morfometriji krških polja još su uvijek predmet rasprava. Dok neki autori smatraju da veličina polja nije značajna (Ford i Williams, 2007), drugi definiraju minimalnu širinu polja od četiristo metara $(\mathrm{Gams}, 1978)$ ili od jednog do pet kilometara (Jennings, 1985; White, 1988).

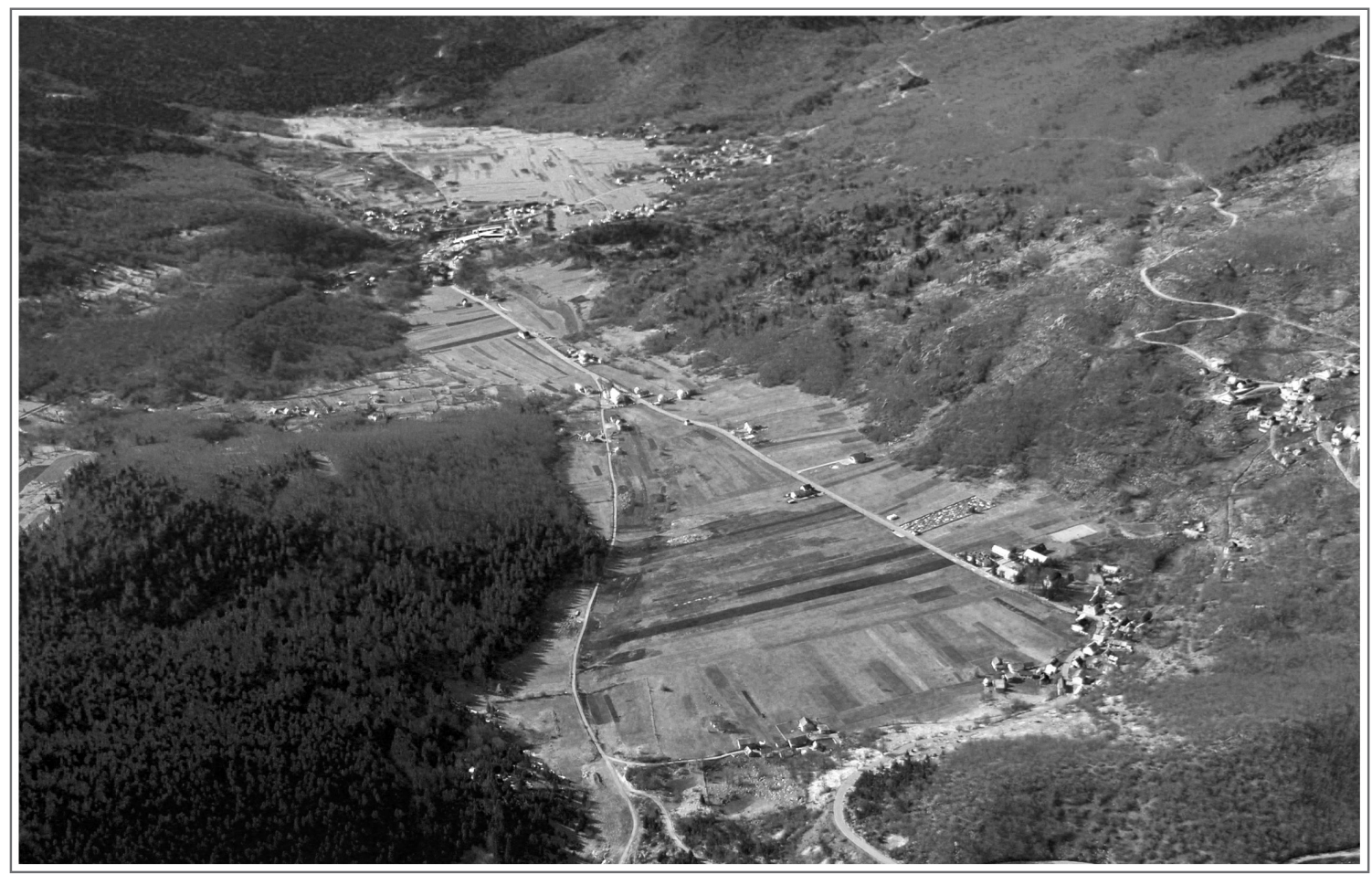

Fig. 3 Aerial photograph of Veliko polje and Jerkuše area

SI. 3. Zračna snimka Velikog polja i Jerkuša 


\section{Research Methods}

Geomorphologic analysis of the area of Krasno polje was conducted by applying analytic geomorphological methods (Pavlopoulos et al., 2009). Morphographic analyses included identification and spacial documentation of geomorphological features in the area of Krasno polje and the surrounding slopes through the use of topographic maps in scales of 1:5000 and 1:25 000, and through detailed morphographic mapping in the field. The morphographical mapping that was carried out in the field was accompanied by morphometric analysis of landforms such as moraine ridges, erractics, glacial outwash plains, suffusion sinkholes and riverbeds. Morphometric data regarding landforms was obtained in the field using barometric altimeters and GPS. The morphometric analyses were supported by analysis of topographic maps and morphostructural analyses of glacial and proglacial sediments were conducted in exposed profiles. The analysis included roundness, shape and surface textures (Evans and Benn, 2004; Coe et al, 2010). Morphochronological analyses was based on assumed analogy with comparable areas of the Dinaric Mountains.

\section{Morphographic, morphometric and morphostructural analysis of Krasno polje}

Within our fieldwork, which included morphographic, morphometric and morphostructural analyses, we came across evidence of glacial processes on the southern and south-western slopes above Krasno polje, which is essential for the morphogenetic interpretation of the polje and surrounding area.

The most extensive geomorphological traces of glaciation are in the Žestikovac area where two sets of lateral moraine ridges emerge on an elevation of $1100 \mathrm{~m}$ and terminate at an elevation of about $850 \mathrm{~m}$, above the Jerkuše area. Those moraines had already been identified within earlier studies (Bognar et al., 1991a; Bognar et al., 1991b; Faivre, 1991). The moraines height is up to $80 \mathrm{~m}$ with length at about $1.1 \mathrm{~km}$. Two major lateral moraine ridges are flanking a gully and some small recessional moraine ridges. Those main moraine ridges are well-preserved and they are entirely composed of non-lithified material. Glacial deposits that were found in exposed profiles in the lower section of the northern

\section{Metode istraživanja}

Istraživanje Krasnog polja provedeno je primjenom analitičke geomorfološke metode (Pavlopoulos i dr., 2009). Morfografske analize uključile su identifikaciju i prostornu dokumentaciju geomorfoloških oblika na području Krasnog polja i okolnih padina upotrebom topografskih karata TK 1:5000 i TK 1:25 000 te primjenom detaljnoga morfografskoga kartiranja na terenu. Morfografsko kartiranje provedeno je na terenu zajedno s morfometrijskom analizom geomorfoloških oblika kao što su grebeni morena, eratičkih blokova, proglacijalnih plavina, sufuzijskih ponikva i riječnih korita. Morfometrijski podaci o geomorfološkim oblicima prikupljeni su na terenu upotrebom barometarskog altimetra i GPS-a. Morfometrijske analize provedene su na osnovi analize topografskih karata, a morfostrukturne analize glacijalnih i proglacijalnih sedimenata na otvorenim profilima. Analize sedimenata obuhvaćale su zaobljenost, oblik i površinsku teksturu (Benn i Evans, 2010; Coe i dr., 2010). Morfokronološka analiza temelji se na analogiji sa sličnim područjima Dinarskog gorja.

\section{Morfografska, morfometrijska i morfostrukturna analiza Krasnog polja}

Tijekom terenskog istraživanja te morfografskih, morfometrijskih i morfostrukturnih analiza pronađeni su dokazi glacijalnih procesa na južnim i jugozapadnim padinama iznad Krasnog polja, značajni za morfogenetsku interpretaciju samog polja i okolnog područja.

Najveći geomorfološki tragovi glacijacije nalaze se na predjelu Žestikovac, gdje su ustanovljena dva bočna grebena morena koja imaju vršne dijelove na visini od 1100 metara i završavaju na visini od oko $850 \mathrm{~m}$ iznad predjela Jerkuše. U tom su dijelu prethodni autori identificirali čeone morene (Bognar i dr., 1991a, 1991b; Faivre, 1991). Njihova je visina do $80 \mathrm{~m}$, a duljina oko 1,1 km. Među dvama glavnim bočnim grebenima morena nalaze se jaruga te manji grebeni recesijskih morena. Grebeni glavnih morena izvrsno su sačuvani te su u potpunosti od nelitificiranog materijala. Glacijalni su depoziti u profilima donjih dijelova sjeverne bočne morene od
Krasno polje on Velebit Mountain: morphographic and morphogenetic characteristics

Krasno polje na Velebitu: morfografske i morfogenetske karakteristike 
HRVATSKI

GEOGRAFSKI

GLASNIK

77/2, 85-99 (2015.) lateral moraine consist of non-sorted glaciogenic material. Some of the bigger clasts are covered by striae. The sediments are composed of Lower Jurassic grey, dark grey and spotted limestone and calcarenite.Approximately $200 \mathrm{~m}$ east of the major lateral moraine ridge is a less typical parallel ridge, which is well-lithified. This ridge is about $300 \mathrm{~m}$ long and over $7 \mathrm{~m}$ high and it is composed of typical non-sorted and lithified glaciogenic material, whose lithological composition corresponds to non-lithified moraines.

South east from Žestikovac are two cirques: Splitvine and Ripljevica. The Splitvine cirque is $600 \mathrm{~m}$ wide and $700 \mathrm{~m}$ long with its floor at an elevation of $1200 \mathrm{~m}$. The Riplevica cirque, which is 500 metres wide and $600 \mathrm{~m}$ long, is smaller, with its floor at an elevation of $1140 \mathrm{~m}$. Both floors of the cirques, Splitvine and Ripljevica, are covered by slope material, while several moraine ridges cover the lowest rims. In profiles at road cuttings on the rims of the cirque, non-lithified glaciogenic material is exposed, which is composed of lower Jurassic grey and dark grey limestone. The slopes below the cirques are covered by glacial material. Moraine ridges are not preserved on the steep slopes, so it is impossible to reconstruct the extent of those two cirque glaciers. Some $100 \mathrm{~m}$ above the polje floor in the area of Trapolovica is a gentler slope with more extensive cover of glacial or proglacial material, which has been previously identified tipičnoga nesortiranoga glaciogenog materijala. $\mathrm{Na}$ većim klastima uočene su i strije. Morene čine donjojurski sivi, tamnosivi i mrljasti vapnenci te kalkarenit. Oko $200 \mathrm{~m}$ istočno od glavnoga bočnoga grebena morene nalazi se manje istaknuti usporedni greben morene koji je potpuno litificiran, dug oko $300 \mathrm{~m}$ i visok preko $7 \mathrm{~m}$, od tipičnoga nesortiranoga i litificiranoga glaciogenog materijala čiji je litološki sastav isti kao i kod nelitificiranih morena.

Jugoistočno od Žestikovca nalaze se dva cirka: Splitvine i Ripljevica. Cirk Splitvine širok je oko $600 \mathrm{~m}$ i dug oko $700 \mathrm{~m}$, a dno mu je na nadmorskoj visini od $1200 \mathrm{~m}$. Cirk Ripljevica, širine $500 \mathrm{~m}$ i duljine $600 \mathrm{~m}$, nešto je manji, a dno mu je na visini od $1140 \mathrm{~m}$. Dna obaju tih cirkova pokrivena su padinskim materijalom, a njihovi niži obodi s nekoliko grebena morena. U profilima uz cestu na obodu cirka nalazi se nelitificirani glaciogeni materijal koji čine donjojurski sivi i tamnosivi vapnenci. Padine podno cirkova prekrivene su glacijalnim materijalom. Na strmim padinama morenski grebeni nisu sačuvani, pa je nemoguće rekonstruirati veličine tih dvaju cirknih ledenjaka. $\mathrm{Na}$ predjelu Trapolovica, oko $100 \mathrm{~m}$ iznad razine polja, nalazi se umjerena padina s većim pokrovom glacijalnog i proglacijalnog materijala koji je već identificiran u literaturi (Bognar i dr., 1991a, 1991b).Od Trapolovice se niz

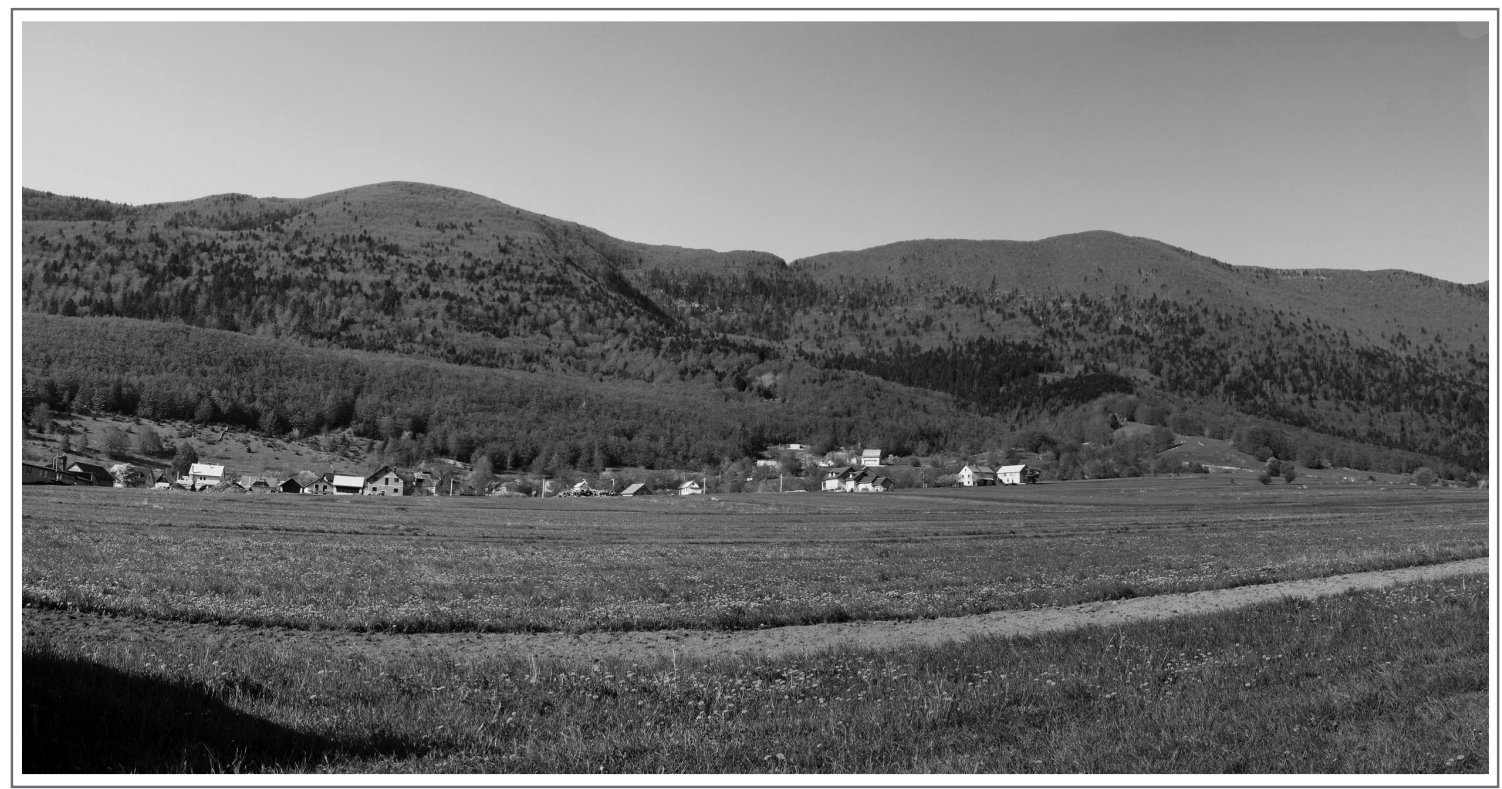

Fig. 4 The Žestikovac Valley with extensive latteral moraines

SI. 4. Dolina Žestikovac s velikim bočnim grebenima morena 
in literature (Bognar et al., 1991a; Bognar et al., 1991b). Downslope from Trapolovica is a gully entrenched into bedrock, which terminates on the southern slopes of the Veliko polje.

The floor of the polje is divided into three seg- padinu pruža jaruga koja je usječena u živu stijenu i završava na južnim padinama Velikog polja.

Dno polja podijeljeno je u tri veća segmenta. Najveći segment polja Jerkuše nalazi se na sjeverozapadu i smješten je podno velikih morena u dolini

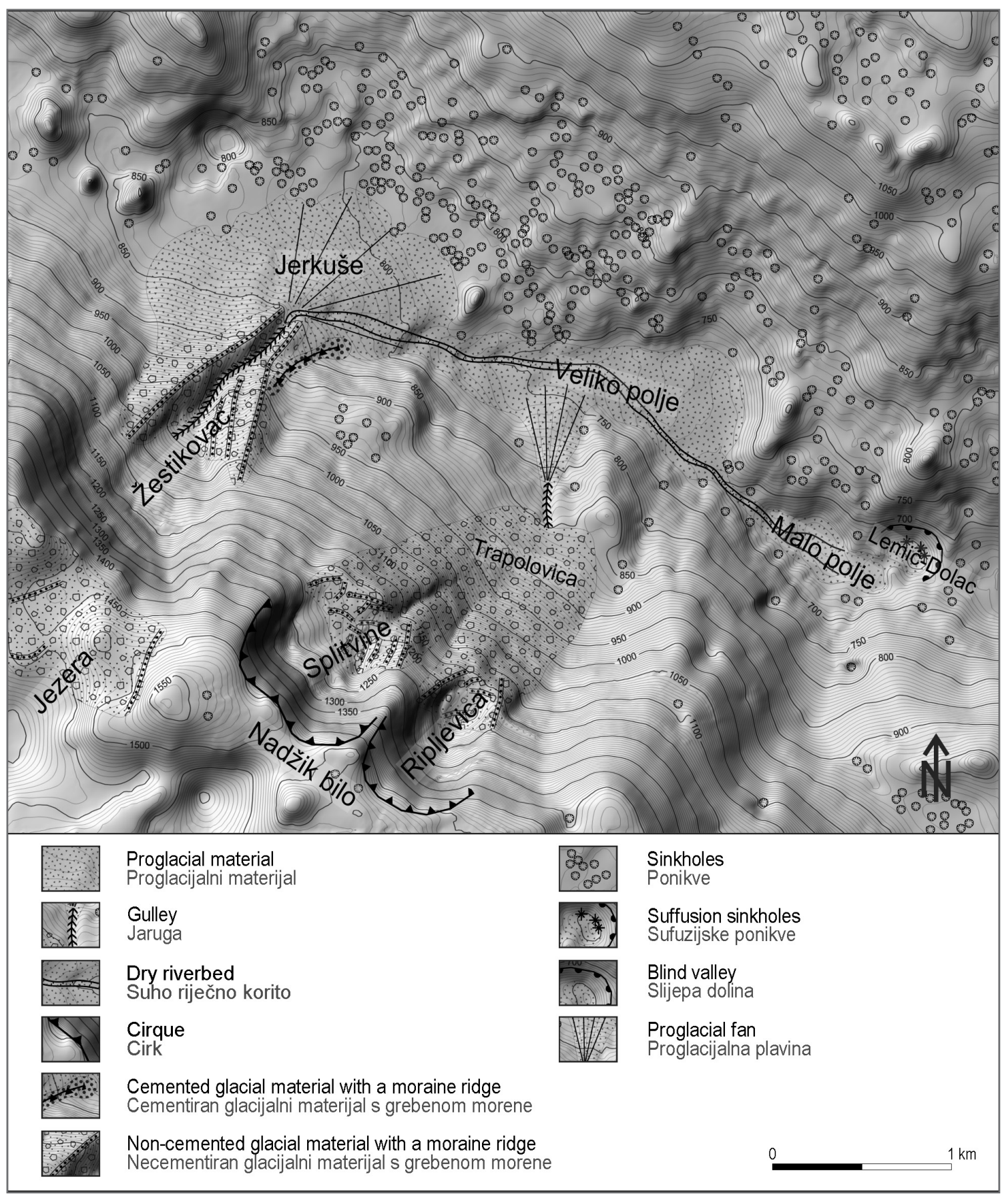

Fig. 5 Geomorphologic map of the Krasno polje area

SI. 5. Geomorfološka karta područja Krasnog polja 
GEOGRAFSKI

GLASNIK

77/2, 85-99 (2015.) ments. The largest segment, Jerkuše, is situated on the north-westernmost part, just below the extensive moraines of Žestikovac valley. The whole area is covered by an extensive proglacial fan, which gradually terminates on the northern and eastern sides of the area. Just below the moraines, the gully extends into a dry riverbed orientated in an easterly direction onto Veliko polje. In its upper section, the riverbed it is up to $15 \mathrm{~m}$ deep and $50 \mathrm{~m}$ wide, while in the lower section of the fan it gradually widens and becomes shallower. The gap between Jerkuše and Veliko poljes is almost $150 \mathrm{~m}$ wide, and it hosts a dry riverbed. In this section, proglacial alluvium cover thins, as bedrock is exposed in some places. Veliko polje is completely covered by the continuation of the proglacial fan from the Jerkuše area. It is inclined towards the east, hosting a dry riverbed along its whole length. In the middle part of Veliko polje, bedrock is exposed in the riverbed. The western side of the polje is partially covered by a smaller proglacial fan, which was formed just below the gully leading from the Trapolovica area.The riverbed extends from Veliko polje towards the southeast in a narrow breach, which is partially filled with alluvium and partially entrenched into a bedrock. Malo polje is situated below this gap. Malo Polje is covered by a proglacial fan in its upper section, while the lower section of the polje is flattened by loamy sediment. A construction site profile in the upper part of Malo polje revealed that the material is non-lithified, well-stratified, and composed of gravel and sandy layers. The lower section of Malo polje extends into a blind valley named Lemić-Dolac. The blind valley, which terminates at a $25 \mathrm{~m}$ high escarpment, is entirely filled by fine-grained material in which two suffusion sinkholes are positioned.

\section{Discussion}

Krasno polje is situated on the Northern Velebit Mountain between the elevations of 660 and $850 \mathrm{~m}$ a.s.l. It is distinctly lengthened along the northwest - southeast direction. It consists of three widened areas that are connected by a uniform floor. The floor is completely infilled by an alluvium and is slightly inclined towards the south-east. The maximum width of the polje is $800 \mathrm{~m}$, while its total length is $1700 \mathrm{~m}$. The flattened floor of the polje covers an area of 1.7 $\mathrm{km}^{2}$. The rim of the polje is higher than the floor, so
Žestikovac. Cijelo područje pokriveno je velikom proglacijalnom plavinom koja postupno završava na sjevernoj i istočnoj strani područja. Odmah podno morene jaruga se nastavlja u suho riječno korito koje se pruža u smjeru istoka i Velikog polja. $\mathrm{U}$ gornjem je dijelu to korito duboko do $15 \mathrm{~m}$, a široko $50 \mathrm{~m}$, da bi se na donjem dijelu proglacijalne plavine postupno širilo i postajalo pliće. Razmak između Jerkuša i Velikog polja iznosi oko $150 \mathrm{~m}$, a u njemu se nalazi i suho korito. $U$ tom se predjelu proglacijalni aluvijalni pokrivač stanjuje jer je živa stijena mjestimično istaknuta. Veliko polje tako je $\mathrm{u}$ potpunosti pokriveno nastavkom proglacijalne plavine od područja Jerkuše. Nagnuto prema istoku, sadržava suho riječno korito cijelom duljinom. U srednjem dijelu Velikog polja izražena je živa stijena i u riječnom koritu. Južna strana polja djelomično je pokrivena manjom proglacijalnom plavinom formiranom podno jaruge koja vodi od područja Trapolovica. Od Velikog polja prema jugoistoku na području suženja proteže se riječno korito djelomično ispunjeno aluvijem, a djelomično usječeno u živu stijenu. Podno spomenutog suženja nalazi se Malo polje. Malo polje u gornjem je dijelu pokriveno proglacijalnom plavinom, a u donjem zaravnjeno ilovastim sedimentom. Pregledom profila na gradilištu u gornjem dijelu Malog polja ustanovili smo prisutnost nelitificiranog i dobro stratificiranog materijala koji se sastoji od šljunka i pješčanih slojeva. Donji dio Malog polja nastavlja se na slijepu dolinu Lemić-Dolac. Slijepa dolina, koja završava podno padine visoke 25 metara, u potpunosti je popunjena finim zrnatim materijalom u kojem se nalaze dvije sufuzijske vrtače.

\section{Rasprava}

Krasno polje nalazi se na sjevernom Velebitu na nadmorskoj visini od 660 do $850 \mathrm{~m}$. Izrazito je izdužena oblika u smjeru sjeverozapad-jugoistok. Sastoji se od tri veća područja povezana jedinstvenim dnom. Dno je u potpunosti ispunjeno aluvijem i lagano nagnuto prema jugoistoku. Najveća je širina polja $800 \mathrm{~m}$, a duljina $1700 \mathrm{~m}$. Ravno dno polja prekriva površinu od $1,7 \mathrm{~km}^{2}$. Rub polja veći je od njegova dna, tako da, prema stručnoj literaturi, ispunjava sve teoretske, morfografske, morfometrične 
it fulfils all theoretical morphographic, morphometric and function criteria for being classified as a karst polje according to literature (e.g. Cvijić, 1890; Grund, 1903; Gams, 1974; Bognar et al., 1991a; Bognar et al., 1991b; Faivre and Reiffsteck, 1999; Faivre, 2007).

A fault line predetermines the position of Krasno polje, which is one of the most expressed morphostructural units in the area of Northern Velebit. Krasno polje is situated in an area of lowered relief, which developed along the fault from the Oltari pass towards Kosinjsko polje (Sokač et al., 1970).

The slopes south and southeast of Krasno polje were intensively altered by glacial action during the Pleistocene. In this area we identified two well-expressed cirques and a valley from an outlet glacier. The Splitvina and Ripljevica cirques to the southeast developed just below the ridge of Nadžik bilo. Some distinct moraine ridges are preserved only on the lowest rims of the cirques. Slopes below the cirques are covered by glacial or fluvio-glacial material. The accumulations were intensively modified by slope processes, so it is not possible to determine the exact extent of the cirque glaciers. Traces of proglacial flows can be found in material evenly distributed along the slopes below the cirques, which have already been mentioned in previous literature (Bognar et al., 1991a; Bognar et al., 1991b; Faivre, 1991). Below the accumulations is a well expressed gully, which terminates just above the middle section of Veliko polje. The gully terminates at the apex of the extensive fluvio-glacial fan that covers part of this section of the polje.

The outlet glacier valley, Žestikovac, was misinterpreted in previous literature as a cirque (Bognar et al., 1991a; Bognar et al., 1991b; Faivre, 1991). This was because an extensive plateau glacier, which occupied most of the Jezera high plateau, was partially draining along Žestikovac valley. In the highest part of the valley on the edge of the Jezera plateau, extensive glacial accumulations with several distinct moraine ridges have been preserved. The steep slopes of the upper section of the valley are of bedrock. Yet just below them, extensive glacial accumulations with distinct lateral moraines are preserved. Lateral moraines in the study area are up to $80 \mathrm{~m}$ high and $1.1 \mathrm{~km}$ long. The lateral moraines increase in height down-glacier, where they separate from the valley walls and converge in the lowest section above the polje, forming a lateral-terminal i funkcionalne kriterije za klasificiranje kao krško polje (npr. Cvijić, 1900; Grund, 1903; Gams, 1978; Bognar i dr., 1991a, 1991b; Faivre i Reiffsteck, 1999; Faivre, 2007).

Položaj Krasnog polja predodređen je rasjedom koji je jedna od najizraženijih morfostrukturnih jedinica na području sjevernog Velebita. Krasno polje smješteno je na području sniženog reljefa koje se pruža uzduž rasjeda od prijevoja Oltari prema Kosinjskom polju (Sokač i dr., 1970).

Južne i jugoistočne padine uz Krasno polje intenzivno su izmijenjene djelovanjem ledenjaka tijekom pleistocena. $\mathrm{Na}$ tom području dva su vrlo izražena cirka i dolina odtočnog ledenjaka (engl. outlet glacier). Cirkovi Splitvina i Ripljevica na jugoistoku, razvijeni su podno grebena Nadžik bilo. Istaknuti grebeni morena sačuvani su samo na najnižim rubovima cirka. Padine podno cirka pokrivene su glacijalnim ili fluvioglacijalnim materijalom. Budući da su akumulacije intenzivno modificirane padinskim procesima, nije moguće utvrditi točan opseg cirknih ledenjaka. U materijalu ravnomjerno raspoređenom duž padina podno cirkova spomenutima u literaturi, moguće je pronaći tragove proglacijalnih tokova (Bognar i dr., 1991a, 1991b; Faivre, 1991). Ispod akumulacija dobro je izražena jaruga koja završava podno srednjeg dijela Velikog polja, u gornjem dijelu proglacijalne plavine koja prekriva dio tog predjela polja.

Dolina odtočnog ledenjaka u Žestikovcu u literaturi je bila pogrešno protumačena kao cirk (Bognar i dr., 1991a, 1991b; Faivre, 1991) jer je veliki ledenjački plato koji je zauzimao veći dio Jezera djelomično otjecao duž doline Žestikovac. Na najvišem dijelu te doline, na rubu platoa Jezera, sačuvane su veće glacijalne akumulacije s nekoliko istaknutih grebena morena. Strme padine viših predjela doline Žestikovac čini živa stijena. No neposredno ispod, sačuvane su velike ledenjačke akumulacije s istaknutim bočnim morenama. Bočne morene na našem su istraživačkom području do $80 \mathrm{~m}$ visine i $1,1 \mathrm{~km}$ duljine. Njihova visina povećava se prema donjem dijelu ledenjaka, gdje se odvajaju od padina doline i konvergiraju u najniže predjele polja tvoreći bočno-čeoni kompleks morena (engl. lateral-terminal morraine complex). U nižem predjelu doline nalazi se manja neaktivna jaruga među bočnim
Krasno polje on Velebit Mountain: morphographic and morphogenetic characteristics

Krasno polje na Velebitu: morfografske i morfogenetske karakteristike 
GEOGRAFSKI

GLASNIK

77/2, 85-99 (2015.) moraine complex. In the lower section of the valley is a small non-active gully in between the lateral moraines. The gully terminates at the apex of an extensive fluvio-glacial fan, which covers the whole area of Jerkuše, the highest section of Krasno polje. Traces of proglacial flows are preserved in a well-expressed dry riverbed, which begins at Jerkuše and extends through a narrow gap towards Veliko polje and further on towards Malo polje.

The whole area of Krasno polje is composed of two proglacial fans. The most extensive is the fan with its apex below the lateral-terminal moraines of the Žestikovac valley, which covers all three segments of the polje: Jerkuše, Veliko polje and Malo polje. An additional fan, which originated from proglacial flows from Splitvina and Ripljevica cirque glaciers, covers the western part of Veliko polje. There is no geomorphologic evidence that would support suggestions that the dry riverbed of proglacial flows would have been active in the Holocene, and that it drained during the Dubrovnik earthquake in 1667 (Glavičić, 1981). The proglacial flows drained after retreat of the glacier towards the end of the Pleistocene. Since Krasno polje was filled by extensive quantities of proglacial alluvium during the Pleistocene, we can conclude that, according to hydrological functions typology (Gams, 1974), Krasno polje is a piedmont type polje.

Within our research, we identified complex depositional structures in the outer section of Žestikovac's extensive lateral-terminal moraine ridges. Lower sections of moraine ridges are built of two sets of separated moraines. Older external moraine ridges are composed of well-cemented material, which is remodelled on the surface by karren. However, the inner ones, which are younger, are neither remodelled by small scale karst features nor cemented. Even though the chronology of glacial events in the Dinaric Mountains remains unclear, the time frame of those glacial accumulations can be derived through analogy to uranium-series dating of secondary carbonates cement within moraines in the southern Dinaric Mountains (Hughes et al., 2010; Hughes et al., 2011), to cosmic radionuclide dating of erratics on Šar Planina Mountain (Kuhlemann et al., 2009) and to some other studies concerning glaciations of the Dinaric Mountains (Stepišnik et al., 2009; Stepišnik and Žebre, 2011; Žebre and Stepišnik, 2014). It was established that ce- morenama. Jaruga završava u vršnom dijelu velike fluvijalno-glacijalne plavine koja pokriva čitavo područje Jerkuša, koje je ujedno i najviši predio Krasnog polja. Tragovi proglacijalnih tokova sačuvani su u dobro izraženome suhom riječnom koritu koje počinje u Jerkušama te se nastavlja prema Velikom polju i dalje prema Malom polju.

Cijelo područje Krasnog polja čine dvije proglacijalne plavine. Najveća plavina, sa svojim vršnim dijelom smještenim podno bočno-čeone morene u dolini Žestikovac, pokriva sva tri veća segmenta polja: Jerkuše, Veliko polje i Malo polje. Dodatna plavina, koja je nastala proglacijalnim tokovima iz ledenjačkih cirkova Splitvine i Ripljevice, pokriva zapadni dio Velikog polja. Ne postoje geomorfološki dokazi koji bi potvrdili pretpostavke da je suho riječno korito proglacijalnih tokova bilo aktivno $\mathrm{u}$ holocenu i da je presušilo uslijed potresa u Dubrovniku 1667. (Glavičić, 1981). Proglacijalni su tokovi naime iscrpljeni nakon povlačenja ledenjaka krajem pleistocena.

Budući da je Krasno polje bilo ispunjeno velikim količinama proglacijalnog aluvija tijekom pleistocena, prema hidrološko-funkcionalnoj tipologiji (Gams, 1978) možemo zaključiti da je Krasno polje piedmontski tip polja.

U ovom istraživanju identificirane su i složene depozitne strukture u vanjskom dijelu Žestikovačkoga velikog bočno-čeonog morskoga grebena. Niži dijelovi grebena morene izgrađuju dvije skupine razdvojenih morena. Stariji vanjski greben morene čini dobro cementiran materijal koji je na površini preoblikovan škrapama. Unutrašnji, mlađi grebeni u međuvremenu nisu preoblikovani manjim krškim tvorevinama niti su cementirani. Unatoč tome što kronologija glacijacije u Dinarskom gorju nije u potpunosti jasna, vremenski okvir tih glacijalnih akumulacija može se pretpostaviti analogijom s uran-torij datacijama sekundarnih karbonatnih cementa u glacijalnim akumulacijama u južnome Dinarskom gorju (Hughes i dr., 2010, 2011), s datacijom kozmičkih radionuklida eratičkih blokova na Šar Planini (Kuhlemann i dr., 2009) te s ostalim studijama morfokronologije glacijacije Dinarskoga gorja (Stepišnik i dr., 2009; Stepišnik i Žebre, 2011; Žebre i Stepišnik, 2014). Tim analizama utvrđeno je da cementirani, dobro okršeni depoziti, sačuva- 
mented, well-karstified deposits, which are preserved only in patches, are the product of older glacial events, while non-lithified well-preserved accumulations are of Last glacial maximum (LGM). Therefore, we conclude that non-lithified moraine ridges in the study area are neither MIS 12 nor MIS 6, but in fact belong to the LGM. Meanwhile, cemented, well-karstified moraine ridges, which are composed of poorly preserved patches in the lowest section of the Žestikovac valley, are of older glacial events, presumably of MIS 6 . On the basis of the Žestikovac moraine ridge chronology, we can establish that the formation of Krasno polje is connected to at least two major glacial events. The karst depression in the area of the polje was partially filled by proglacial alluvium in the earlier MIS 6 glacial event, while the extent of today's alluvial cover of the polje can be connected to LGM.

\section{Conclusion}

Large corrosion plains, canyons and intramontane depressions hosting karst poljes dissect the Dinaric Mountains. Krasno polje is positioned in the northern part of Velebit Mountain, which is the largest continuous massif in the Dinaric Mountains. On the basis of synthesis of morphographic and morphometric field data and comparison with the records from literature, we have established:

1. Krasno polje is a closed depression filled by Tertiary sediment with its rim being higher than its floor. Therefore, according to all factors including its dimensions, it fits the morphographic and morphometric requirements for being defined as a polje.

2. The position of lowered relief in which the polje is situated is predefined by Krasno polje fault. The long axis of the polje is orientated along this geologic structure.

3. Southern and south-eastern slopes above the polje were intensively modified by glacial action. Two cirque glaciers and an outlet glacier were positioned on the slopes. Glacial accumulations cover vast areas of the slopes. Some glacial accumulations in the Žestikovac valley are organised in specific types of glacial depositional landforms, referred to as lateral-terminal moraine complexes. ni samo u tragovima, predstavljaju tragove starijih glacijacija, dok su nelitificirane dobro sačuvane akumulacije rezultat posljednjega glacijalnog maksimuma (LGM). Stoga zaključujemo da nelitificirani grebeni morena na ovom istraživačkom području nisu MIS 12 (engl. marine isotope stage) ni MIS 6, već pripadaju posljednjemu glacijalnome maksimumu (LGM). Osim toga cementirani, dobro okršeni grebeni morena koji čine slabo sačuvane zakrpe u najnižem predjelu doline Žestikovac vjerojatno pripadaju MIS 6. Na osnovi kronologije grebena morene u Žestikovcu možemo ustvrditi da je nastanak Krasnog polja povezan s barem dva glavna glacijalna događaja. Krška depresija na području polja djelomično je ispunjena proglacijalnim aluvijem $u$ ranijem MIS 6, dok se većina današnjega aluvijalnog pokrivača polja može povezati s LGM-om.

\section{Zaključak}

Dinarsko gorje sadržava velike korozijske zaravni, kanjone i međuplaninske depresije s krškim poljima. Krasno polje smješteno je na sjevernom dijelu planine Velebit, najvećemu kontinuiranome planinskome masivu Dinarskoga gorja. $\mathrm{Na}$ osnovi sinteze morfografskih i morfometrijskih terenskih podataka te usporedbe $s$ podacima iz literature ustanovili smo:

1. Krasno polje zatvorena je depresija ispunjena tercijarnim sedimentom koja ima sve rubne dijelove više od dna. Prema svim čimbenicima i s obzirom na svoje dimenzije, Krasno polje ispunjava sve morfografske i morfometričke kriterije da ga se definira kao polje.

2. Položaj sniženog reljefa u kojem je smješteno polje predodređeno je rasjedom Krasnog polja. Duža os polja orijentirana je uz tu geološku strukturu.

3. Južne i jugoistočne padine iznad polja intenzivno su modificirane djelovanjem ledenjaka. Ledenjačke akumulacije pokrivaju velika padinska područja. Neke glacijalne akumulacije $\mathrm{u}$ dolini Žestikovac organizirane su u određenom tipu glacijalnih depozitnih oblika koje nazivamo bočno-čeonim morenskim kompleksima.
Krasno polje on Velebit Mountain: morphographic and morphogenetic characteristics

Krasno polje na Velebitu: morfografske i morfogenetske karakteristike 
HRVATSKI

GEOGRAFSKI

GLASNIK

77/2, 85-99 (2015.)
Literature Literatura
4. Extensive lateral-terminal moraine complexes in the Žestikovac valley are believed to be a product of several glacial events. Older external moraine ridges are composed of well- cemented material, while the inner ones are well-preserved and are not cemented near the surface. On the basis of analogy to the morphochronology of glacial deposits from the southern part of the Dinaric Mountains (Kuhelmann et al., 2009; Hughes et al., 2010; Hughes et al., 2011), we assume that non-lithified moraine ridges in the study area derive from the LGM. Meanwhile, cemented moraine ridges in the lowest section of the Ž estikovac valley are of MIS 6.

5. The whole floor of the polje is filled with proglacial deposits. The most extensive section is the proglacial fan which extends away from Žestikovac valley through the whole of Jerkuše and most of the Veliko polje area. A smaller proglacial fan extends over the western part of the Veliko polje area. Fluvioglacial material also covers the lowest part of Malo polje.

6. There is no evidence that the dry riverbed in the polje floor would have been active up to the $\mathrm{Du}$ brovnik earthquake in 1667, as literature suggests (Glavičić, 1981). We believe that the riverbed hosted Pleistocene proglacial streams, because it extends from the middle part of Žestikovac valley further down along the whole length of the polje. On the other hand, it is highly unlikely that extensive surface flow would emerge on the surface so high above the phreatic zone after the Pleistocene.

7. Since Krasno polje is thoroughly filled by fluvioglacial deposits, we can suggest that it is a piedmont type of polje according to the hydrological function classification system (Gams, 1978).
4. Za velike bočno-čeone morenske komplekse u dolini Žestikovac smatramo da su produkt nekoliko glacijalnih razdoblja. Stariji vanjski greben sastavljen je od dobro cementiranog materijala, dok je unutrašnji dobro sačuvan i nije cementiran u blizini površine. $\mathrm{Na}$ osnovi analogije s morfokronologijom glacijalnih depozita južnog dijela Dinarskoga gorja (Kuhlemann i dr., 2009; Hughes i dr., 2010, 2011) pretpostavljamo da nelitificirani morenski greben na prostoru Krasnog polja potječe iz posljednjega glacijalnog maksimuma (LGM). Cementirani morenski greben u najnižem dijelu doline Žestikovac pripada MIS 6.

5. Čitavo dno polja ispunjeno je proglacijalnim depozitom. Najveći dio čini proglacijalna plavina koja se pruža od doline Žestikovac kroz cijele Jerkuše i veći dio područja Velikog polja. Manja proglacijalna plavina proteže se preko zapadnog dijela područja Velikog polja. Niže predjele Malog polja prekriva fluvioglacijalni materijal.

6. Ne postoje dokazi da je riječno korito u polju bilo aktivno do potresa u Dubrovniku 1667. kako to sugerira literatura (Glavičić, 1981). Budući da se pruža od srednjeg dijela doline Žestikovac i cijelom duljinom polja, smatramo da je riječno korito proizvod pleistocenskih proglacijalnih tokova. S druge strane, malo je vjerojatno da će se veći površinski tokovi pojaviti na površini tako visoko iznad freatične zone nakon pleistocena.

7. Budući da je polje temeljito popunjeno fluvioglacijalnim depozitom, možemo zaključiti da je Krasno polje piedmontski tip polja prema sustavu hidrološke funkcionalne tipologije (Gams, 1978).
Benn, D. I., Evans, D. J. A., 2010: Glaciers and Glaciation, New York.

Bognar, A., Faivre, S., Pavelić, J., 1991a: Glacijacija Sjevernog Velebita, Senjski zbornik 18 (1), 181-196.

Bognar, A., Faivre, S., Pavelić, J., 1991b: Tragovi oledbe na Sjevernom Velebitu, Geografski glasnik 53 (1), 27-39.

Coe, A., Argles, T., Rothery, D., Spicer, R., 2010: Geological field techniques, Chichester.
Cvijić, J., 1900: Karsna polja zapadne Bosne i Hercegovine (Die Karstpoljen in Westbosnien und in Herzegowina), Glas Srpske kraljerske akademije nauka 59 (1), 59-182.

Faivre, S., 1991: Geomorfološke osobine Sjevernog Velebita. Diplomski rad, Zagreb.

Faivre, S., 2007: Analyses of the Velebit Mountain Ridge Crests, Hrvatski geografski glasnik 69 (2), 21-40.

Faivre, S., Reiffsteck, P., 1999: Spatial distribution of dolines as an indicator of recent de- formations on the Velebit mountain range (Croatia)/La répartition spatiale des dolines comme indicateur de contraintes tectoniques. Montagne de Velebit (Croatie), Géomorphologie: relief, processus, environnement 5 (2), 129142.

Ford, D., Williams, P. D., 2007: Karst Hydrogeology and Geomorphology, Chichester.

Gams, I., 1978: The polje : the problem of definition: with special regard to the Dinaric karst, Zeitschrift für Geomorphologie 22 (2), 170-181. 
Gavrilović, D., 1974: Srpska kraška terminologija, Beograd.

Gèze, B., 1973: Lexique des termes français de spéléologie physique et de karstologie, Annales de speleologie 28 (1), 1-20.

Glavičić, A., 1981: Nalazi kamenih gromila na Velebitu, Senjski zbornik 9 (1), 33-42.

Grund, A., 1903: Die Karsthydrographie: Studien aus Westbosnien, Geographischen Abhandlungen 7 (1), 103-200.

Hughes, P. D., Woodward, J. C., van Calsteren, P. C., Thomas, L. E., 2011: The glacial history of the Dinaric Alps, Montenegro, Quaternary Science Reviews 30 (23-24), 3393-3412.

Hughes, P. D., Woodward, J. C., van Calsteren, P. C., Thomas, L. E., Adamson, K. R., 2010: Pleistocene ice caps on the coastal mountains of the Adriatic Sea, Quaternary Science Reviews 29 (27-28), 3690-3708.

Jennings, J. N., 1985: Karst Geomorphology, Oxford.

Kuhlemann, J., Milivojević, M., Krumrei, I., Kubik, P. W., 2009: Last glaciation of the Šara range (Balkan Peninsula): increasing dryness from the LGM to the Holocene, Austrian Journal of Earth Sciences 102 (1), 146-158.

Lehmann, H., 1959: Studien über Poljen in den venezianischen Voralpen und im Hochapennin, Erdkunde 13 (4), 258-289.

Medvedović, J., Milković, J., Tomaić, M., 2009: Neke značajke vremena i klime Krasna i okolnog područja, Šumarski list 11-12 (1), 613622.

Mihevc, A., 2010: Geomorphology, u: Introduction to Dinaric karst (ur. Mihevc, A., Prelovšek, M., Zupan Hajna, N.), IZRK ZRC SAZU, Postojna, 30-43.

Mojsisovicz, E., 1880: Zur Geologie der Kars Erscheinungen, Jabrbuch der Geologische Reichsanstalt 30 (3), 1-30.

Monroe, W. H., 1970: A Glosary of Karst Termi nology Washington.

Pavlopoulos, K., Evelpidou, N., Vassilopoulos, A., 2009: Mapping Geomorphological Environments, Berlin Heidelberg.

Perica, D., Bognar, A., Lozić, S., 2002: Geomorphological features of the Baške Oštarije karst polje, Geoadria 7 (2), 23-34.

Perica, D., Orešić, D., 1999: Klimatska obilježja Velebita i njihov utjecaj na oblikovanje reliefa, Senjski zbornik 26 (1), 1-50.

Roglić, J., 1964: Les Poljé du karst dinarique et les modifications climatiques du quaternaire, Revue Beige de Geographie 88 (1), 105-125.
Sokač, I., Bahun, S., Velić, I., Galović, I., 1970: Osnovna geološka karta 1:100.000, Tumač za list Otočac, K33-115, Beograd.

Stepišnik, U., Ferk, M., Kodelja, B., Medenjak, G., Mihevc, A., Natek, K., Žebre, M., 2009: Glaciokarst of western Orjen, Cave and karst science 36 (1), 21-28.

Stepišnik, U., Kosec, G., 2011: Modelling of slope processes on karst, Acta Carsologica 40 (2), 267-273.

Stepišnik, U., Žebre, M., 2011: Glaciokras Lovče$n a$, Ljubljana.

Sweeting, M. M., 1973: Karst Landforms, New York.

Šerko, A., 1947: Kraški pojavi v Jugoslaviji, Geografski vestnik 19 (1), 43-70.

Velić, I., Velić, J., 2009: Od morskih plićaka do planine, Geološki vodič kroz nacionalni park Sjeverni Velebit, Krasno.

White, W. B., 1988: Geomorphology and hydrology of karst terrains, Oxford.

Žebre, M., Stepišnik, U., 2014: Reconstruction of Late Pleistocene glaciers on Mount Lovćen, Montenegro, Quaternary International 353 (0), 225-235.
U. Stepišnik

Krasno polje on Velebit Mountain: morphographic and morphogenetic characteristics

Krasno polje na Velebitu: morfografske i morfogenetske karakteristike 